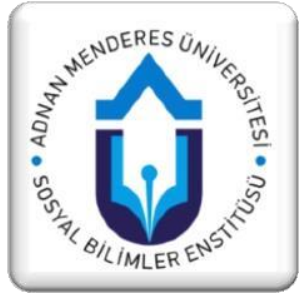

\section{İşgücü Piyasaları Bağlamında Endüstri 4.0 Kavramına İlişkin Üniversite Öğrencilerinin Metaforik Görüssleri}

\author{
Olcay BESNILI MEMIŞ̧ ${ }^{1}$
}

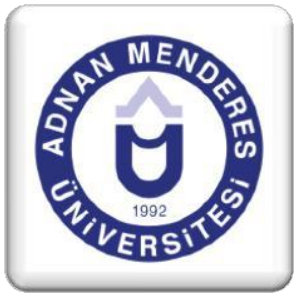

Makale Gecmisi

Başvuru Tarihi:02.04.2021

Kabul Tarihi:24.06.2021

\author{
Article History \\ Date of Application:02.04.2021
}

Acceptance Date:24.06.2021

\title{
Özet
}

$\mathrm{Bu}$ araştırmanın temel amacı, işgücü piyasaları bağlamında Endüstri 4.0 kavramına ilişkin üniversite öğrencilerinin sahip oldukları görüşleri, metaforlar aracılığıyla analiz etmektir. Araştırma; nitel araştırma metodolojisine uygun olarak tasarlanmıştır. Araştırmanın çalışma alanı, Atatürk Üniversitesi'dir. Katılımcılar, kriter örnekleme yöntemi kullanılarak belirlenmiştir. İşü̈cü piyasana yönelik müfredata sahip ve yakın zamanda işgücü piyasasına katılacak olmaları nedeniyle Çalışma Ekonomisi ve Endüstri İlişkileri Bölümü öğrencilerinden dördüncü sınıflar, çalışmanın katılımcıları olarak belirlenmiştir. Katılımcılara metaforlar oluşturmaları için, "Bana göre Endüstri 4.0 işgücü piyasası için ............. gibidir, çünkü............." ifadesinin yazılı bulunduğu formlar çevrimiçi ortamda gönderilmiş ve boşlukları doldurmaları istenmiştir. Araştırma sonunda 33 geçerli metafor oluşturulmuş ve bu metaforlar 3 farklı kategori altında toplanmıştır. Buna göre, üniversite öğrencileri; Endüstri 4.0 kavramını işgücü piyasaları bağlamında bir firsat, tehdit ve belirsizlik olarak algılamaktadır. Temalar, cinsiyetlere göre ayrıca değerlendirilerek, kadın öğrenciler özelinde incelenmiştir. Sonuç olarak öğrencilerin, Endüstri 4.0 ile ilgili firsatlar ve tehditler bakımından tutarlı görüşlere sahip olduğu ancak yeterli düzeyde farkındalık geliştirmedikleri belirlenmiştir.

Anahtar Kelimeler: Endüstri 4.0, işgücü piyasaları, metafor, eğitim

Jel Kodları: F66, J24, E24

\section{The Metaphoric Opinions of University Students in The Context of Labor Markets Regarding The Concept of Industry 4.0}

\begin{abstract}
The main purpose of this research is to analyze the opinions of university students regarding the concept of Industry 4.0 in the context of labor markets by using metaphors. The research was designed in the qualitative research methodology. Participants were determined using the criterion sampling method. Fourth-grade students in the Department of Labor Economics and Industrial Relations were participants of the research. To create metaphors, they were sent semi-structured forms online and they were asked to fill in the blanks "I think, Industry 4.0 is like ............ for the labor market, because .............". At the end of the research, 33 metaphors were produced and these metaphors were collected in three different categories. Accordingly, university students perceive the Industry 4.0 concept as an opportunity, threat, and uncertainty in the context of labor markets. The themes were evaluated with genders and examined in particular for female students. As a result, students have consistent opinions but; have not a sufficient level of awareness, about Industry 4.0.
\end{abstract}

Keywords: Industry 4.0, labor market, metaphor, education

Jell Codes: F66, J24, E24

\footnotetext{
${ }^{1}$ Araş. Gör., Atatürk Üniversitesi, İktisadi ve İdari Bilimler Fakültesi, Çalışma Ekonomisi ve Endüstri İlişkileri Bölümü, olcay.besnili@atauni.edu.tr, ORCID ID: 0000-0003-1821-2143
} 


\section{Giriş}

Endüstri 4.0 kavram1, dördüncü endüstri devrimini temsil etmekte ve dijitalleşme ile karakterize edilmektedir. Önceki endüstriyel devrimler, buhar gücünün üretim süreçlerinde kullanılması (birinci), montaj hatlarında seri üretime geçiş ve çelik üretimi (ikinci), mikroçip teknolojisi ve biyoteknoloji yoluyla süreçlerin otomasyonunu (üçüncüsü) içermektedir (Thoben, Wiesner ve Wuest, 2017: 1). Dördüncü sanayi devrimi ise, üretim süreçlerinde dijitalleşmenin artması ve dijital değer zincirlerinin oluşturulduğu bir süreci temsil etmektedir. (Lasi, Fettke, Kemper, Feld ve Hoffmann, 2014: 239; Oesterreich ve Teuteberg, 2016: 122). Sürecin en önemli fark1; gerçek zamanlı veri alışverişi yoluyla bireylerin, nesnelerin ve sistemlerin birbirine bağlanmasıdır. Bu bağlamda, bilgi ve iletişim teknolojileri uygulamaları, veri analitiği, yapay zekâ, üç boyutlu baskı, bulut bilişim, nesnelerin interneti, robotlar, genetik ve biyoteknoloji gibi alanların gelişip güçlendiği bir süreç söz konusudur. (Mokyr, Vickers ve Ziebarth, 2015: 42).

Endüstri 4.0'ın kendisinden önceki tüm endüstriyel devrimler gibi, üretimde yeni yöntem ve teknolojilerin geliştirilmesiyle birlikte, sosyo-ekonomik ve politik sistemlerde köklü bir değişime neden olması beklenmektedir (Schwab, 2016; Pianta, 2018). Bu anlamda; toplumların, yönetimlerin ve insanların nasıl bir değişimle karşı karşıya oldukları, araştırılması gereken bir sorun olarak karşımıza çıkmaktadır. Bu çalışmada söz konusu sorun, insan özelinde ele alınmaktadır ve ekonomik bir aktör olarak işgücünün değişimlerden nasıl etkileneceği incelenmektedir.

Literatürde, teknolojik değişimlerin işgücü piyasası üzerindeki etkilerini inceleyen çalışmalar mevcuttur. Etkilerin, işgücü piyasası için firsatlar yarattığını savunan çalışmalar olduğu kadar, tehditler içerdiğini savunan çalışmalar da söz konusudur. Firsatlar yarattığını savunan çalışmalar genellikle, gelişmiş ülkelerin işgücü piyasasını yeniden düzenleme kapasitesine odaklanmaktadır (Autor, 2015: 1559; Deming, 2017: 1598; Arntz, Gregory ve Zierahn, 2016; Dünya Ekonomik Forumu (WEF), 2016). Buna göre, teknolojik dönüşüm işletmelerede yeni üretim süreçlerinin geliştirilmesi ve yeni ürünlerin üretilmesi anlamına gelecektir. İşletmeler bu sayede; daha rekabetçi, daha üretken ve pazarlarını genişletme eğiliminde olacaklardır. Teknolojik ürün ve üretim süreçlerine yatırımlarda bir artış beklenmektedir ve her bir yeni yatırım, yeni bir istihdam olanağı olarak kabul edilmektedir. Ayrıca, yeni oluşan istihdamda koşulların işgücü lehine oluşması, beden ve zihin gücünün yoğun taraflarının robotlar tarafindan yapılması ve işgücüne daha az emek sarf etme avantajı sağlayacağ1 savunulmaktadır (Gabriel ve Pessl, 2016: 131). Aynı şekilde, işgücünün daha fazla özerklik kazanacağı da belirtilmektedir (Schumacher ve ark., 2016: 162). Bir başka firsat, çalışma koşullarının esnek hale gelerek, işgücünün daha iyi bir iş-yaşam dengesi kurmasının mümkün olacağı belirtilmektedir (Bauer, Hämmerle, Schlund ve Vocke, 2015: 418-419). Ancak; sürecin anlatıldığ1 gibi gerçekleşmesi için, işgücünün de sürece uyum sağlaması beklenmektedir. Buna göre, yeni teknolojiler sayesinde özellikle; temel, düşük ve orta düzey beceri gerektiren işlerin piyasadan kalkması beklenmektedir. Yeni oluşan işler, dijital becerilerin talep edildiği içeriklere sahip olacaktır. Bir başka deyişle, mevcut işler ve işlerin gerektirdiği beceriler güncelliğini yitirecek; yeni iş süreçleri ve gerekleri, yeni becerilerin talep edilmesine neden olacaktır. Böylece; işgücünün kişisel becerilerini ve yeteneklerini, yeni teknolojik yapılarla bütünleştirerek geliştirmesi gerektiği vurgulanmaktadır (Freddi, 2018: 395).

Bir tehdit olarak ele alınan çalışmalar, robotların insanların yaptığı her şeyi yapabileceği fikri üzerine temellendirilmiştir. Böylece, işgücünün işsizlik riski ile karş1 karşıya olduğu savunulmaktadır. İşsizlik işgücü piyasasında, birçok çalışma koşullarında değişiklik yaratma potansiyeline sahip bir olgu olduğundan önemlidir. Bu nedenle, hangi işlerin teknolojik 
dönüşüme daha duyarlı olduğu ile ilgili araştırmalar yapılmaktadır. Amerika'da mevcut işlerin teknolojik gelişmelere ne kadar duyarlı olduğunu araştıran Frey ve Osborne (2017: 265), 702 meslek için işlerin \%47'sinin risk altında olduğunu bulmuşlardır. Bu işler büyük oranda, kendini tekrar eden, bilişsel süreçler içermeyen işlerdir. Bununla birlikte, işsizliğin yoğun görüldüğü işgücü piyasalarında, ilk tepki olarak ücretlerde bir düşüş görülmesidir. Acemoğlu ve Restrepo (2017), çalışmalarında bu beklentiyi kanıtlayarak, Amerika Birleşik Devletleri işgücü piyasasında robot kullanımının ücretleri yüzde 0,25-0,5 oranında düşürdüğünü bulmuşlardır.

İşgücü piyasası için, teknolojik işsizlik ve teknolojiye bağlı çalışma koşullarında değişiklik, yeni tartışılan bir konu değildir, ancak; Endüstri 4.0 döneminde daha fazla endişe yaratmaktadır. Bazı ülkelerde; muhasebeci, kasiyer ve telefon operatörlerinin tüm işlevleri başta olmak üzere, bir dizi işin yerini robotların alması bu endişenin gerekçesini oluşturmaktadır (Manyika, Chui, Bughin, Dobbs, Bisson ve Marrs, 2013: 43). Endüstri 4.0 yaygınlaştıkça, iş ve mesleklerin gerekleri sürekli güncellenecektir. Buna göre; talep edilen becerilerin, bilişim ve yumuşak beceriler (soft skills) olması tahmin edilmektedir. Yumuşak beceriler, iletişim, liderlik, problem çözme ve iş birliği yapabilme becerileri gibi becerileri kapsamaktadır. (Gabriel ve Pessl, 2016: 133; Deming 2017: 1600). Bununla birlikte, teknolojik gelişmeler sayesinde sürekli güncellenen ürün ve üretim süreçleri, talep edilen becerilerin de değişmesine neden olacaktır. Bugün ne olduğu bilinmeyen bir iş veya meslek gelecekte ortaya çıkabilecek ve aynı şekilde, hiç bilinmeyen bir beceriyi talep edebilecektir. Böylece, işgücünün sürekli olarak yeni bilgi ve yetenekler geliştirmesi bir zorunluluk halini alacak, işsizlik riskine karşı robotlarla rekabet etmek zorunda kalacaktır (Bauer ve ark., 2015: 420).

Talep edilen becerilere sahip işgücü arzının eksikliği, piyasada hem açık işlerin hem de işsizliğin yoğun görülmesine neden olacaktır. Makroekonomik dengenin bozulmasına yol açacak bu iki durumun çözümlenmesi, Endüstri 4.0'a köklü bir hazırlık yapmaya dayanmaktadır. Böylece, Endüstri 4.0'a yönelik eğitim ve öğretim programlarında revizyona gidilmesi gibi politikaların yanında, işgücü piyasasında talep ve arzın arasındaki potansiyel boşluğun analiz edilmesi ve doldurulması için aktif politikaların hayata geçirilmesi gerekmektedir. Politikaların daha fazla işletmeler düzeyinde gerçekleştirilmesi litaratürde tartışılan bir konudur. Buna göre işletmelerin, Endüstri 4.0'a özel yönetim stratejileri geliştirmeleri, kendi çalışanlarına özel dijital beceri geliştirme yöntemleri gibi yetkinlikler kazandırması ve yeni nesil çalışanların ihtiyaç duydukları çalışma ortamının sağlanması için çalışmalar yapması beklenmektedir (Richert, Shehadeh, Plumanns, Groß, Schuster ve Jeschke, 2016: 142). Ancak; bu düzenlemelerin hayata geçirilen işletmenin dışında önemli bir faydası olmayacaktır. Her yıl çok sayıda kişi ve yeni mezun üniversite öğrencisi işgücü piyasasına katılmaktadır. Talep edilen beceriler ile ilgili makro düzeyde bir politikanın eksikliği, öğrencileri ve diğer kişilerin yapısal işsizlik yaşamasına neden olacaktır. İşsizlik süreci uzadıkça, kişilerin istihdam edilebilirliği düşmektedir. Böylece işsizliğin kronik hale gelmesi söz konusu olacak, ekonomik ve sosyal eşitsizlikler toplumda adalet va barışın bozulmasına neden olacaktır. $\mathrm{Bu}$ anlamda, kamusal düzlemde politikaların gerçekleştirilmesi, toplumsal barış ve adaletin sağlanması için bir gereklilik olarak kabul edilmelidir. (Vieira Alves, 2020: 227).

Ülkemiz ele alındığında, üretim tesisleri ile uluslararası katma değer zincirinde yer aldığı konumu Endüstri 4.0 döneminde de koruması belirsizdir. Doğrudan yabanc1 yatırımlar, teknolojik gelişmelerin maliyet ve verimlilik avantajını etkin kullanan bir başka ülkeye yapıldığ 1 takdirde, önemli istihdam alanları kaybedilecektir. Bu anlamda, Endüstri 4.0'1n birlikte getirdiği yeni güncellemeleri içselleştirmek önemlidir. Konu ile ilgili 
Cumhurbaşkanlığg ve Millî Eğitim Bakanlığ1 plan ve programlarında, atılmıș önemli adımalar mevcuttur. Söz konusu programlarda, mesleki ve teknik eğitimlerin işgücü piyasas1 ile bağlantısı kurularak güncellenmesi hedeflenmiştir. Hiç kuşkusuz bu adımlar çok önemli ve gereklidir. Ancak, toplumun tüm kesimlerini kapsayan ve özellikle Yükseköğretim Kurumlarında bir dönüşümü işaret etme özelliklerini taşımamaktadır. Bu anlamda, bilişim sektörü ile ilgili bölümler dışında, birçok bölümde kazandırılan becerilerin gelecekte istihdam edilebilirliğe katkı sunmayacağ endişesi söz konusudur. Ancak bu endişenin yeterli bir farkındalık oluşturmadığı kanaati de hâkimdir. Ülkelerin üretim sistemi, teknoloji ve beceri setleri ile ilgili hangi durumda olduklarının farkına varması, hazırlıklı olmak için önemlidir. Nitekim farkındalık, kamusal düzlemde talep edilmelidir. Kanun koyucu ve politika üreticileri yönlendirmek, Endüstri 4.0'a daha aktif hazırlanmayı sağlayabilecektir. $\mathrm{Bu}$ anlamda, toplumda işgücünü potansiyelini oluşturan ve görece yakın zamanda işgücü piyasasına katılacak üniversite öğrencilerinin konu ile ilgili farkındalık geliştirip geliştirmediklerini belirlemek bu çalışmanın motivasyonunu oluşturmaktadır. Öğrencilerin, bu dönem için ne gibi yargılar geliştirdiklerinin belirlenmesi, farkındalık düzeylerine yönelik önemli kanıtlar sunacaktır. Farkındalık düzeylerinin yeterince gelişmemiş olması, belirlenmiş alanlar dışında eğitim ve istihdam faaliyetlerinin güncellenmesi gereğinin altını çizicektir. Bu anlamda çalışma, öğrencilerinin algılarına göre Endüstri 4.0 hazırlanmak için yeni argümanlara ihtiyaç olup olmadığg ile ilgili katkılar sunabilecektir.

\section{Araştırmanın Kapsamı}

Bu bölümde araştırmanın; amacı, metodolojik alt yapısı, modeli, katılımcılarının belirlenmesi, görüşme formunun hazırlanması, veri toplama teknikleri ve süreci ile ilgili bilgiler verilecek, belirlenen kısıtlılıkları açıklanacaktır.

\subsection{Araştırmanın Amacı}

Araştırma; işgücü piyasası için Endüstri 4.0 kavramının ne ifade ettiğini, konu ile ilgili eğitimi bulunan ve yakında işgücü piyasasına girecek olan üniversite öğrencilerinin bakış açısı ile ortaya koymayı amaçlamaktadır. Bu amaç çerçevesinde, aşağıdaki üç sorunun cevabı aranmıştır:

1. Üniversite öğrencileri, işgücü piyasası bağlamında Endüstri 4.0 kavramını hangi metaforları kullanarak ifade etmişlerdir?

2. Üniversite öğrencileri, işgücü piyasası bağlamında Endüstri 4.0 için kullandıkları metaforları hangi gerekçelerle açıklamışlardır?

3. Üniversite öğrencilerinin işgücü piyasası bağlamında Endüstri 4.0'a ilişkin algılarını ifade ettikleri metaforların cinsiyet açısından dağılımları nasıldır?

\subsection{Araştırmanın Metodolojisi}

Araştırma, cevap aranan soruların ölçülebilir bir karşılıkları olmadığı için nitel araştırma metodolojisi üzerine temellendirilmiştir. Nitel araştırmalar, dilin zenginliğinden sıkça faydalanmaktadır. Dilin gizli anlam yapıları ve kalıplarını ortaya çıkarmak için, metaforlar aracılığı ile bilgiye ulaşmak nitel araştırmada kullanılan bir yöntemdir. Metafor kavramını, bir benzerliği ifade etmek için başka bir kavrama yapılan atıf olarak tanımlamak mümkündür. Metaforlara başvurmanın ilk gerekçesi temel kavramsal heterojenliği ortaya koymaktır (Schmitt, 2000). Bu bağlamda araştırma, Endüstri 4.0 ve birlikte gelişen süreçlerin işgücü piyasasına yansımalarını, işgücü piyasasına yeni katılacak üniversite öğrencileri gözünden görmek için, metafor olarak toplanan verileri analiz etmek amaciyla tasarlanmıştır. 


\subsection{Araștırmanın Modeli}

Nitel araştırma metodolojisi, birçok modelde araştırma tasarlamayı mümkün kılmaktadır. Fenomenoloji, bu modellerden biri ve en çok tercih edilenidir. Fenomenoloji, gerçek bilgiye ulaşmak için içerisinde bulunulan andaki deneyim dışında her şeyi göz ardı ederek, bireysel bilincin içeriğine odaklanmaktadır (Eagleton, 1983: 55). Buna göre fenomenoloji; bir fenomenin özünü, onu deneyimlemiş olanların bakış açısıyla keşfederek anlatmaya çalışan bir araştırma yaklaşımı olarak tanımlanabilir (Teherani, Martimianakis, Stenfors-Hayes, Wadhwa ve Varpio, 2015: 669-670). Bu nedenle; çalışmanın odaklandığ1 soru, sorunlar ve hedef kitle göz önüne alındığında, bireylerin deneyimlerinden bilgi çıkarmak gerektiği ve bu bilgiye ulaşmayı kolaylaştıran, fenomenoloji modeli kapsamında tasarlanmasının en doğru yaklaşım olduğu belirlenmiştir.

Toplanan verilerin analizi, nitel araştırmada yaygın kullanılan içerik analizi modeli kullanılarak yapılmıştır. İçerik analizi, fenomenleri açılamak için görsel veya yazılı verileri kullanarak çıkarımlarda bulunmaya olanak tanıyan bir analiz yöntemidir (Downe ve Wambolt, 1992: 313). İçerik analizinin, verileri nesnel ve sistematik bir şekilde verilerin özetlenmesini sağlayan bir yöntem olduğu için çalışmanın amacına uygun olduğu söylenebilir.

\subsection{Katılımcıların Belirlenmesi}

Katılımcılar belirlenirken, iki önemli husus göz önünde bulundurulmuştur. İlki, amaca uygun katılımcıya ulaşmaktadır. İkincisi ise, nitelikli veriye ulaşmaktır. Bu bağlamda, katılımeı seçiminde kriter örnekleme yöntemi belirlenmiştir. Kriter örnekleme, önceden belirlenmiş bazı önem kriterlerini karşılayan durumların seçilmesini içerir (Patton, 2001: 238). Çalışmanın amacı, potansiyel işgücü olan ve görece yakın zamanda işgücü piyasasına katılacak bireylerin Endüstri 4.0 kavramına ilişkin algılarını ortaya koymak olduğundan, 4. Sınıf üniversite öğrencilerinin amaca uygun olacağı belirlenmiş ve ilk kriter karşılanmıştır. Nitelikli veriye ulaşmak için, işgücü piyasası ile ilgili konularda belirli bir hakimiyet düzeyi olan öğrencilerin katılımcı olması ikinci kriter olarak belirlenmiştir. Buna göre, müfredatlarının büyük bir bölümünde işgücü piyasasının işleyişini, sorunlarını ve çözümlerini inceleyen Çalışma Ekonomisi ve Endüstri İlişkileri Bölümü öğrencilerinin uygun olduğu düşünülmüştür. Araştırmacının erişim kısıtları nedeniyle ise, çalışma alanı Atatürk Üniversitesi olarak belirlenmiştir. Bu anlamda, Atatürk Üniversitesi Çalışma Ekonomisi ve Endüstri İlişkileri Bölümü dördüncü sınıf öğrencileri araştırmanın katılımcilarıdır.

\subsection{Görüşme Formunun Hazırlanması}

Görüşme formu kavramsal metafor teorisine uygun olarak oluşturulmuştur. Kavramsal metafor teorisine (Lakoff ve Johnson, 1980: 3-4) göre, iki ana kavramsal alan türü vardır. İlki kaynak alandır ve bu alanda metaforik ifadeler alınmaktadır. İkincisi ise hedef alandır, anlamaya çalışılan kavramın bireysel ifadelerle açıklandığı alandır. Buna göre, çalışmada iki bölümden oluşan bir görüşme formu kullanılmıştır. İlk bölümde katılımcıların cinsiyetleri sorulmuş, ikinci bölümde ise, "Bana göre Endüstri 4.0 işgücü piyasası için gibidir, çünkü............." ifadesindeki boşlukların doldurulması istenmiştir. Kaynak alanda, katılımcılardan işgücü piyasası bağlamında Endüstri 4.0 kavramını nasıl algıladıklarını tanımlayan bir metafor kullanmaları istenmiştir. Hedef alanda ise, katılımcıların seçtikleri metaforu seçme gerekçesini açıklamaları ve daha ayrıntılı olarak detaylandırmaları istenmiştir. Ayrıca, görüşme formunun üzerinde metaforun tanımı ve katılımcılardan alınan görüşlerin makale için kullanılacağına dair bilgilendirme yer almaktadir. 


\subsection{Veri Toplama Süreci ve Kısıtlılıklar}

Veri toplama süreci, Atatürk Üniversitesi Sosyal ve Beşeri Bilimler Etik Kurul Başkanlığı'ndan alınan (Sayı:88656144-000.E.2100023675) etik kurul onay belgesi ile başlamıştır. Veri toplama, araştırmanın pandemi dönemine denk gelmesi nedeniyle yüz yüze ortamda yapılamamıştır. Çevrimiçi postalarla öğrencilere ulaşılarak, çalışmaya katılmayı kabul ettiklerini belirten sözlü onay istenmiş, onay verenlere yarı yapılandırılmış görüşme formu doldurmaları için gönderilmiştir. Bu anlamda, araştırmanın ilk kısıtlılığı yüz yüze görüşmelerin eksikliğidir. Araştırmanın sadece Atatürk Üniversitesi ile sınırlı kalması araştırmanın ikinci kısıtlılığıdır. Daha başka üniversitelerdeki öğrencilere ulaşmanın mümkün olmaması söz konusu kısıtlılığın oluşmasına yol açmıştır.

İlgili programda, aktif olarak seksen yedi öğrencinin olduğu bilinmektedir. Altmışaltı öğrenci çalışmaya katılmayı onaylamış ve gönderilen postaya altmışaltısı da geri bildirimde bulunmuştur. Ancak tüm formların tamamı doldurulmadığı saptanmış, eksik doldurulanlar çıkarıldı̆̆ında elli katılımcının görüşme formu analiz için uygun görülmüştür. Aşağıdaki tabloda, analiz için kodlanmış belge sayısı ve katılımcıların cinsiyet dağılımı, tablo 1 'de görülmektedir.

Tablo 1: Kodlanmış Belgeler

\begin{tabular}{llll} 
& Frekans & Yüzde & Yüzde (geçerli) \\
\hline Kadın & 30 & 60.00 & 60.00 \\
Erkek & 20 & 40.00 & 40.00 \\
Kodlanmış BELGELER & 50 & 100.00 & 100.00 \\
Kodlanmamış BELGELER & 0 & 0.00 & - \\
& & & - \\
ANALIZ EDİLEN BELGELER & 50 & 100.00 & \\
\end{tabular}

Tablo'ya göre, elli adet belgede kodlama işlemi yapılmış ve bu belgelerden otuz tanesinin kadın öğrencilere, yirmi tanesinin ise erkek öğrencilere ait olduğu görülmektedir.

\subsection{Veri Analiz Süreci}

Analizi uygun olan belgeler, .doc formatına dönüştürülerek, nitel araştırmaların analizine olanak tanıyan MAXQDA 2020 yazılım programına aktarılmıştır. Verilerin ilk okuması program üzerinden gerçekleşmiş ve temalar belirlenmiştir. Birkaç kez daha okumanın ardından, metin üzerinde kodlama işlemleri yapılmıştır. Kodlamalar, okumalarla eşanlı olarak açık kodlama tekniği ile yapılmıştır. Alt kodlar bir araya getirilerek eksen kodlama tekniği uygulanmış ve kategoriler belirlenmiştir. Kategoriler ise araştırma sorularına göre temalaştırılmıştır. Böylece, metodolojinin gerektirdiği gibi, nitel veriler önce en küçük parçalara ayrılmış, daha sonra birleştirilerek analiz süreci tamamlanmıştır. 


\section{Araştırmanın Bulguları}

$\mathrm{Bu}$ bölümde, araştırma kapsamında elde edilen görüşlerin analizine ilişkin sonuçlar yer almaktadır. Analiz, araştırmada kullanılan formun hedef alanındaki görüşlerin kategorize edilmesi ile yapılandırılmıştır. Bir başka deyişle, katılımcıların kullandıkları metaforlar, neden o metaforu kullandıklarını açıklayan görüşleri doğrultusunda değerlendirilmektedir. Buna göre katılımcılar, işgücü piyasası için Endüstri 4.0'1 bir firsat, belirsizlik ve tehdit olarak görmektedirler. Tablo 2, görüşmelerden elde edilen metaforları göstermektedir.

Tablo 2: Görüșmelerden Elde Edilen Metaforlar

\begin{tabular}{l|l|l}
\hline Fırsat içerikli metaforlar & Belirsizlik içerikli metaforlar & Tehdit içerikli metaforlar \\
\hline yeni sürüm/güncelleme- 4 & kalem & insansız çă̆-4 \\
zaman-2 & naylon poşet & acı biber \\
zirve & limon & hastalık \\
sihirbaz & dipsiz kuyu & bomba \\
hızır & rüzgâr & virüs \\
aydınlık & sinav & canavar \\
sihir & akıntı & enter tuşu \\
anne & hormonlu süt & hırsız \\
& & cellat \\
\hline
\end{tabular}

Tabloda görülen temalar, başlıklar şeklinde verilerek ilgili metaforlar incelenecektir. Ayrıca temalar, ek bir başlık altında görüşlerin cinsiyet dağılımları bakımından da analiz edilecektir.

\subsection{Fursat olarak Endüstri 4.0}

Katılımcılardan oniki kişi, Endüstri 4.0'1 işgücü piyasası için bir firsat olarak gördügünü belirten sekiz metafor üretmişlerdir. Tablo 2 incelendiğinde, katılımcılar işgücü piyasası için Endüstri 4.0'1 en fazla yeni sürüm/güncelleme metaforu ile tanımladıkları görülmektedir. İkinci olarak ise zaman metaforu kullanarak tanımlamışlardır. Zirve, sihirbaz, hızır, aydınlık, sihir ve anne metaforları ise birer katılımcının görüşlerini tanımlayan metaforlardır.

Endüstri 4.0'1 işgücü piyasası için bir firsat olarak gören katılımcılar, genellikle yeni oluşacak düzenin işgücü piyasasında önemli değişikliklere yol açacağını, ancak; bu değişimin işgücü için olumsuz sonuçlardan uzak olduğu inancını taşımaktadır. Örnek olarak şu görüşler gösterilebilir:

K16: Endüstri 4.0 işgücü piyasası için, yeni sürüm gibidir. Çünkü; her şeyde olduğu gibi işgücü piyasasında yenilikler ve olumlu geliş̧meler olacaktır....

K18: Endüstri 4.0 işgücü piyasası için, zaman gibidir. Çünkü; zaman klymetlidir. Teknolojinin hızla gelişmesi hızla, seri ve daha az emekle üretimi artıracaktır, zamandan tasarruf edilerek en klymetliye erişilmiş olacaktır. Üretim hacmine hızla ulaşıldığında, işgücü artık uzun çalışma saatlerine mahkûm olmayacak, ailesi ile geçireceği en klymetli boş zamana erişmiş olacaktır. 
İfadelerden de görüldügü gibi metaforlara yüklenen firsat içeren anlamlar, birbirlerini tamamlar niteliktedir. Yeni sürüm ya da güncelleme metaforunda, işlerin yenilenmesi ve buna bağlı olarak; işgücünün çalışma koşullarının yenilenmesi için firsatlar yarattığından bahsetmektedir. Aynı şekilde zaman metaforunda, uzun çalışma saatlerinin son bulması ve işgücünün daha fazla boş zamana ulaşma şansının olacağı düşünülmektedir. Zirve metaforunda, Endüstri 4.0'ın ekonomik katkılarının çok fazla olması işgücünün de ücretinde bir artış olarak anlaşılmıştır. Sihirbaz, sihir ve aydınlık metaforları, işlerin kolaylaşmasını, beceriler edinmenin ve iş bulmanın kolaylaşmasını, yoksulluk ve kötü çalışma koşullarının son bulacağını tanımlamaktadır. Hızır ve anne metaforları, Endüstri 4.0'ın işgücüne yardımcı olacağına ve böylece işgücünün üzerindeki iş yükünün azalmasına neden olacağını tanımlamaktadır.

Görüşmelerden elde edilen, firsat nitelikli metaforlar, literatürle uyumludur. Acemoğlu ve Restrepo (2017), robotların kullanımının işgücünün istihdam koşulları üzerinde önemli bir etkisinin olmadığını bulmuşlardır. Katılımcıların görüşlerinden anlaşıldığı üzere, Endüstri 4.0'1 bir olarak firsat görenler, istihdamda önemli bir etki beklememektedir. Aynı şekilde, katılımcıların özellikle Endüstri 4.0'ın işgücü için olumlu çalışma koşulları ile verimlilik anlamın geldiğini belirtmeleri Graetz ve Michaels (2018)'ın çalışması ile paralellik göstermektedir. Çalışmaya göre, robot kullanımı işgücü verimliliğine yıllık olarak katkıda bulunmakta, toplam faktör verimliliğini artırmakta, çıktı fiyatlarını düşürmekte ve toplam istihdamı önemli ölçüde azaltmadığı savunulmaktadır. Bu anlamda katılımcılar, Endüstri 4.0'ın firsatlar içeren tarafına farkındalık geliştirmiş olarak görülmektedir.

\subsection{Belirsizlik olarak Endüstri 4.0}

Katılımcılardan sekizi kişi, Endüstri 4.0'1 işgücü piyasası için bir belirsizlik olarak gördüğünü belirten sekiz metafor üretmişlerdir. Tablo 2'de görüldüğg̈ gibi, katılımcılar tek bir metaforda yoğunlaşmamışlardır. Kalem, naylon poşet, limon, dipsiz kuyu, rüzgâr, akıntı, sınav ve hormonlu süt gibi metaforlar üretilmiştir. Bu kategorinin altındaki görüşler, özellikle Endüstri 4.0 ile ilgili belirsizlikleri çok iyi betimleyebilmişlerdir. Bu nedenle katılımcıların görüşlerinin birebir aktarımının daha faydalı olacağı düşüncesiyle, bazıları aşağıda paylaşılacaktır.

K32: Endüstri 4.0 işgücü piyasası için, limon gibidir. Çünkü; dışı tatlı sarıdır ama içi tatlı mı çıkar ekşi mi çıkar önce tatmak lazım.

K27: Endüstri 4.0 işgücü piyasası için, kalem gibidir. Çünkü; işgücü piyasasında kurallarl yeniden yazacak, ancak ne yazacak ben de merakla bekliyorum.

K37: Endüstri 4.0 işgücü piyasası için, rüzgâr gibidir. Çünkü; rüzgâr gibi esecektir. Vurur mu geçer, kırar mı geçer, okşar mı geçer orası net değil.

K50: Endüstri 4.0 işgücü piyasası için, dipsiz kuyu gibidir. Çünkü ne kadar ileri gidilebilir ne kadarda duracaktır hiç belli değildir. Makineleşmenin seviyesi işgücü piyasasını etkileyecektir ama sonuç olarak; ya gerçekten çok fazla işsizlik olacak, her aşamada robotlara talep olacaktır ya da gerçekten işgücünün emek yoğun, yorucu ve insanın onuruna yakışmayan iş ve çalışma biçimlerinden kurtulmasına neden olacaktır.

Katılımcıların tüm görüşleri dikkate alındığında, işgücü piyasasının bir dönüşüm ve değişim geçireceği ile ilgili fikir birliğinin oluştuğunu, ancak bu değişimin net olarak olumlu ya da olumsuz olduğunu belirlemekten kaçındıklarını söylemek mümkündür. Net sonucu belirlemek için henüz erken olduğunu düşünmeleri, görüşlerinden anlaşılmaktadır. $\mathrm{Bu}$ yaklaşımları literatürde genel kanının tam bir yansımasını içermektedir. Endüstri 4.0 gerçekten, işletmeler için (Birkel, Veile, Müller, Hartmann ve Voigt, 2019), ülkeler için 
(Arntz ve ark., 2016) ve işgücü piyasası için (Autor ve Dorn, 2013; Fujiwara ve Zhu, 2020) belirsizlikler içermektedir.

\subsection{Tehdit olarak Endüstri 4.0}

Katılımcılardan onüç kişi, Endüstri 4.0'1 işgücü piyasası için bir tehdit olarak gördügünü belirten on metafor üretmişlerdir. Katılımcıların kullandıkları metaforlar ilk anlamlarıyla dahi olumsuz anlam taşımaktadır. Kullandıkları metaforların gerekçelerini açıkladıkları hedef alanda ise, yoğun olarak tehdit olarak nitelikleri durum işgücünün robotlaşma nedeniyle işsiz kalmasıdır. Aşağıda bu nitelikteki görüşlere bir örnek verilmiştir.

K24: Endüstri 4.0 işgücü piyasası için, kara delik gibidir. Çünkü; dünyada işgücünün yoğun olduğu tüm sektörleri içine alarak işsizliği artıracaktır.

Katılımcılardan elde edilen görüşler, işsizliğin artması yönünde ağırlık göstermiştir. Literatürde, yapılan çalışmalardan robotların kullanımının istihdam kayıpları ile sonuçlandığını ampirik olarak inceleyen çalışmalar mevcuttur. Bu çalışmalar, katılımcıların görüşlerini destekler niteliktedir. Arntz, Gregory ve Zierahn (2016), OECD ülkelerinin verilerini kullanarak yaptıkları çalışmada, tüm dünyada yoğun teknolojinin etkilediği sektörler olacağını ancak bu etkinin, hali hazırda teknolojik üretim yapan ülkelere göre, düşük teknoloji ya da işgücü yoğun üretim yapan ülkelerde daha fazla görünür olacağını belirtmişlerdir. Aynı şekilde, Autor ve Salomons (2018), 2007-2011 yılları OECD ülkeleri için yaptıkları analiz sonucunda, otomasyonun istihdamın yerini aldığını ve otomasyonun yoğun olduğu endüstrilerde işgücünün katma değer payının düştüğünü, doğrudan bir etki olarak bulmuşlardır.

Ancak genel olarak herhangi bir etki konusu bildirmeseler de işgücü için olumsuz gelişmelere neden olacağına dair görüşlerde bildirmişlerdi. Tehdit nitelikli metaforlar bildiren katılımcılardan dördü, etkinin konusu hakkında kesin bir görüş bildirmeden, olumsuz senaryodan bahsetmiş̧ir. İfadeleri belirsizliğe yakın olan katılımcılardan direkt bir olumsuzluk belirtmeleri ile ayrılmışlardır. Bu nitelikteki görüşlerden ilginç bulunan iki tanesi aşağıda verilmektedir.

K23: Endüstri 4.0 işgücü piyasası için, hormonlu süt gibidir. Çünkü; süt doğalliğını kaybetti ve artık tereyağın tadı tuzu yok. Tadını bozdukları gibi, yapısını da bozdular. Kim bilir neler yapıyor sağlı̆̆ımıza. Bunların en büyük sebebi üretilen süt ürünlerinin makine aracılığıyla farklı katk maddeleri katarak özünü kaybettirdikten sonra çıktı olarak toplumumuza sunulmasıdır. Endüstri 4.0 daha fazla makineleşme demekse, hormonlu sütten yapılan tereyağl gibi her şey makinelerden geçecek. Tatsı tuzsuz bir hayat olacak.

K13: Endüstri 4.0 işgücü piyasast için, virüs gibidir. Çünkü nasıl ki virüs geldi, tüm dünyada insan alışkanlıkların ve hayatın kökünden değiştirdi, Endüstri 4.0 da aynı şekilde işgücünün alışkanlıklarını ve hayatını değiştirecektir. Bu değişimin olumlu olmayacağ ise aşikardır. Nasıl ki pandemi dönemi küçük esnafi derinden etkiledi ama büyük işletmeleri etkilemedi ise, Endüstri 4.0 da bu hikâyenin küçük esnafi işgücünü derinden etkileyecektir.

Katılımcıların bu ifadeleri ile kısıtlı farkındalık geliştirdiği söylenebilir. Sadece etki konusunu belirtmemeleri değil, işsizliği tek tehdit olarak görmeleri de bu duruma bir gerekçedir. Katılımcılardan hiçbiri, çalışma koşullarındaki değişimden ya da ücretlerdeki düşüş tehlikesinden ifadelerinde bahsetmemişlerdir. 


\subsection{Metaforların Cinsiyete Göre Dağılımı}

İşgücü piyasalarının kalıcı özelliklerinden biri istihdamda cinsiyet ayrımıdır. En baştan işlerin cinsiyete göre ayrıldığı ve "kadın işi" olarak belirlenenlerin düşük statü, olumsuz koşullar ve düşük ücret ile karakterize olduğu bilinmektedir (Peetz ve Murray, 2017). Son yıllarda, kadınlar işgücü piyasasında daha görünür olsalar da, çalışma şartlarında iyileşmelerin olduğunu söylemek mümkün değildir. Bu anlamda, gelecekteki durumları için bir farklılığın olup olmayacağı, Endüstri 4.0 ile ilgili farkındalıklarına bağlıdır. Bu anlamda özellikle kadın öğrencilerin, üç ana tema içerisinden hangisinde yoğunlukla görüş belirttiklerini analiz etmek, genelleştirmeden uzak, küçük bir fikir olarak kadınların farkındalık düzeyine erişmeyi olanaklı hale getirecektir. Aşağıdaki şekilde, tüm temaların cinsiyetlere göre dağıllımı görülmektedir.

Tablo 3: Metaforların Cinsiyete Göre Dağılımı

\begin{tabular}{l|l|l|l|l|l}
\hline \multicolumn{2}{l|}{ Fırsat içerikli metaforlar } & \multicolumn{2}{l|}{ Belirsizlik içerikli metaforlar } & \multicolumn{2}{l}{ Tehdit içerikli metaforlar } \\
\hline Erkek & Kadın & Erkek & Kadın & Erkek & Kadın \\
6 & 6 & 2 & 5 & 9 & 5 \\
Toplam: 12 & Toplam:7 & & \multicolumn{2}{|c}{ Toplam: 14 } \\
\hline
\end{tabular}

Tabloya göre, geçerli olan otuz üç metafordan on altı tanesi kadınlara, on yedi tanesi erkeklere aittir. Fırsat içerikli metaforlarda bir eşitlik söz konusu olmuş, her iki cinsiyetten altı kişi konu ile ilgili görüş bildirmiştir. Ancak, belirsizlik ve tehdit temalarında, kadın öğrencilerin konu ile ilgili yeterince farkındalık düzeyi geliştirmedikleri görülmektedir. Belirsizlik temasında, iki erkek öğrenciye karşı beş kadın öğrencinin görüş bildirmesi ve tehdit temasında, dokuz erkek öğrenciye karşı beş kadın öğrencinin görüş bildirmesi konuyu kanttlar niteliktedir. Özellikle belirsizlik ile ilgili görüşlerden, bu başlıkta değerlendirilmek istenen bir örnek aşağıda verilmektedir.

K19: Endüstri 4.0 işgücü piyasası için, sınav gibidir. Çünkü; sınava gireriz ama hoca sinavın sonucunu okuduktan sonra açıklar. Bu nedenle önce biz önce slnava gireceğiz, daha sonra hocanın okumasını bekleyeceğiz diye düşünüyorum. Başarılı olana ne olacak, başarlsız olana ne olacak bundan sonra göreceğiz.

Katılımcımızın ifadesi, ülkemizin gerçeğinin altını çizmektedir. Herhangi bir olgunun gerçekleşmesini beklemeden önlem almak ya da davranış geliştirmek ne yazık ki ülkemizde bir kültür değildir. Yukarıdaki kadın öğrencinin ifadesinin aksine, kadınlarımızın Endüstri 4.0 döneminde kendi durumlarını değiştirmeleri için sınava daha hazır girmeleri sadece umut edilen değil, zorunlu bir durumdur. Dünya Ekonomik Forumu, Endüstri 4.0'n ABD, Almanya, Fransa, Çin, Brezilya ve diğer ülkeler üzerindeki potansiyel etkisine bakılan bir çalışmaya dayanarak, gerekli önlemler alınmaz ise; işsizlik ve eşitsizliğin geleceğin gündemi olduğunu ve kadınların bu süreçte en ön safhada olacağını belirtmektedir (WEF, 2016).

\section{Sonuç ve Tartışma}

Günümüz çalışma hayatının kısa bir zaman içerisinde dönüşmesi beklenmektedir. İşgücü yoğun işlerin neredeyse ortadan kalktığı, bilişsel iş ve mesleklerin geleceğin mesleği olacağ ve hatta ağırlıklı istihdam yaratacak meslek ve işlerin adının dahi bilinmediği savunulmaktadır (WEF, 2016: 3). Dünyada birçok ülkede bu dönüşümün olas1 etkileri öngörülmekte ve kod yazma eğitimleri anaokulu düzeyindeki çocuklara dahi verilmektedir (Fessakis, Gouli ve Mavroudi, 2013). Ancak ülkemizde, bu çalışmalar kısıtlı ve küçük bir kesim için mümkün durumdadır. Çoğunluğun aldıkları eğitimler, çok kısa bir sürede piyasa ile bağını koparmış, talep edilmeyen niteliklerle anılma tehlikesi içerisindedir. 
Bu çalıșma, potansiyel işgücü piyasası katılımcıları olan üniversite öğrencilerinin hem konu ile ilgili görüşlerine ulaşmak, hem de bu görüşlerin durumun aciliyetini göstermek açısından önemli bir argüman olacağı inancı ile kurgulanmıştır. Araştırma, sorularının ölçüm teknikleri ile bir karşılığı olmadığ 1 için nitel metodoloji üzerine temellendirilmiştir. Bilimsel araştırmalarda, yeni konuların araştırılmasında yararlı bir yöntem olarak kabul edildiğinden, metaforlar aracılığı ile veriler toplanmıştır. Katılımcılar, iki kriter belirlenerek, kriter örnekleme yöntemi ile seçilmiştir. Müfredatı büyük oranda işgücü piyasaları ile ilgili olan Çalışma Ekonomisi ve Endüstri İlişkileri bölümü öğrencilerinden, işgücü piyasasına katılmaları görece daha yakın olan 4. Sınıflar çalışmanın katılımcılarını oluşturmuştur. Katılımcılara çevrimiçi postalar aracılığı ile ulaşılmış, katılımcı olmak için rızaları sözlü olarak alınmış ve yarı yapılandırılmış görüşme formunu doldurmaları istenmiştir. Formun ilk bölümünde, Endüstri 4.0'^ işgücü piyasası bağlamında bir metafor ile tanımlamaları, ikinci bölümde ise neden bu metaforu kullandıklarını gerekçelendirmeleri istenmiştir. Öğrencilerden geri dönen formlardan elli tanesi analize uygun görülmüş ve otuz kadın, yirmi erkek öğrencinin görüşlerinin bildirdiği formlar, içerik analizi metodu ile analiz edilmiştir.

Analiz sonucunda geçerli otuz üç metafor elde edilmiş ve bu metaforlar; firsat, tehdit ve belirsizlik olarak temalandırılmıştır. Öğrenciler, fırsat niteliğindeki metaforları literatürle uyumlu bir şekilde gerekçelendirmişlerdir. Buna göre; istihdam üzerinde bir etki olmamasının yanında, işgücünün de daha az zamanla, daha fazla verimli olarak çalışması Endüstri 4.0'1n getirdiği firsatlar olarak belirlenmektedir. Belirsizlik niteliğindeki metaforlarda; öğrenciler, net ifadeler kullanmadan olumsuz bir dönüşümü ifadelerinde kullanmışlardır. Tehdit niteliğindeki metaforlarda ise, en temel tartışma konusu olan işsizlik ele alınmakta ve buna karşın, ücret gibi çalışma koşullarına özgü bir dönüşüm öğrencilerin ifadelerinde yer almamaktadır. Öğrenciler, Endüstri 4.0 için gerek kişisel gerekse kamusal düzlemde bir eğitim atağına ihtiyaç duyduklarını ifade etmemişlerdir. İşgücü piyasası ile ilgili dönüşümlerde büyük bir endișe duymadıkları, genel ifadelerinden anlaşılmaktadır. Ayrıca, cinsiyete göre ifadelerin hangi temada yoğunlaştığını görmek için ayrı bir başlık açılarak metaforlar analiz edilmiştir. Buna göre, belirsizlik ve tehdit temalarında, kadın öğrencilerin konu ile ilgili yeterince farkındalık düzeyi geliştirmedikleri görülmektedir.

Öğrenciler, becerilerinin Endüstri 4.0 döneminde geçerli ve yeterli olduğu ile ilgili bir endişe yaşamamaktadır. Kamusal düzenlemelerin eksikliğinin yanında, öğrencilerin de yetersiz farkındalığı ülkemizde önemli sorunların oluşmasına neden olabilecektir. Bu nedenle, yaşam boyu öğrenim anlayışı içerisinde, kamunun finans ettiği bir sistemin oluşturulması ve üniversite öğrencilerinin sürece derhal dahil edilmesinin faydalı olacağı düşünülmektedir. Bu sistemde, geleceğin nitelik ve becerileri şimdiden belirlenmeli, piyasada eksik olan ya da hiç olmayanları işgücüne kazandırmak için teşvik ve destekler sağlanmalıdır. Mevcut müfredatlar üzerinde çalışmalar yapılmalı ve geleceğin beceri ve niteliklerini kazandırmak amacıyla güncellenmelidir. Eğitimden sonra işgücü piyasasına geçişin kolaylaştırılması için işgücü piyasasını düzenleyen kurumlar aktif bir rol almalıdır. Kadınlar ise, ayrı bir başlıkta ele alınarak, işgücü piyasasında yeniden dezavantajlı konumda olmaları önlenmelidir. Kadınların teknolojik nitelik ve becerilere ulaşımını kolaylaştırmak için girişimlerde bulunulmalı, istihdam ve çalışma koşullarında eşitliğin sağlanmasında her türlü yasal düzenlemenin yapılması gerekmektedir. Söz konusu girişimler ülkemiz için, toplumsal kalkınmanın yolunu açan yeni bir düzenin takip edeni değil, yol göstereni olmak firsatıdır. 


\section{Kaynakça}

ACEMOGLU, D., \& RESTREPO, P. (2020). Robots and Jobs: Evidence from US Labor Markets. Journal of Political Economy, 128(6), 2188-2244.

ARNTZ, M., GREGORY, T., \& ZIERAHN, U. (2016). The Risk of Automation for Jobs in OECD Countries: A Comparative Analysis. OECD Social, Employment and Migration Working Papers, No. 189. Paris: OECD Publishing.

AUTOR D.H., \& DORN, D. (2013). The growth of low-skill service jobs and the polarization of the US labor market. The American Economic Review, 103(5), 15531597.

AUTOR, D. (2015). Why are there still so many jobs: The history and future of workplace automation. Journal of Economic Literature, 29(3), 3-30.

AUTOR, D., \& SALOMONS, A. (2018). Is Automation Labor ShareDisplacing? Productivity Growth, Employment, and the Labor Share. Brookings Papers on Economic Activity, 1-87.

BAUER, W., HÄMMERLE, M., SCHLUND, S., \& VOCKE, C. (2015). Transforming to a hyper-connected society and economy - towards an "industry 4.0". Procedia Manufacturing, 3, 417-424.

BIRKEL, H.S., VEILE, J.W., MULLER, J.M., HARTMANN, E., \& VOIGT, K.I. (2019). Development of a risk framework for Industry 4.0 in the context of sustainability for established manufacturers. Sustainability, 11(2), 1-27.

DEMING, D. J. (2017). The growing importance of social skills in the labour market. The Quarterly Journal of Economics, 132(4), 1593-1640.

DOWNE-WAMBOLT, B. (1992). Content analysis: method, applications and issues. Health Care for Women International, 13, 313-321.

EAGLETON, T. (1983). Literary theory: An introduction. Oxford: Basil Blackwell.

FESSAKIS, G., GOULI, E., \& MAVROUDI, E. (2013). Problem solving by 5-6 year old kindergarten children in a computer programming environment: A case study. Computers \& Education, 63, 87-97.

FREDDI, D. (2018). Digitalisation and employment in manufacturing. AI \& Soc, 33, 393403.

FREY, C.B., \& OSBORNE, M.A. (2017). The future of employment: how susceptible are jobs to computerisation?. Technological Forecasting and Social Change, 114, 254280.

FUJIWARA, I. \& ZHU, F. (2020). Robots and Labour: Implications for Inflation Dynamics. In Bank for International Settlements (Eds.), Inflation dynamics in Asia and the Pacific (pp. 41-49). Basel, Switzerland: Monetary and Economic Department, ISBN 978-92-9259-342-1.

GABRIEL, M., \& PESSL, E. (2016). Industry 4.0 and sustainability impacts: critical discussion of sustainability aspects with a special focus on future of work and ecological consequences. International Journal of Engineering, 14, 131-136.

GRAETZ, G., \& MICHAELS G., (2018). Robots at work. Review of Economics and Statistics. 100(5), 753-768. 
LAKOFF, G., \& JOHNSON, M. (1980). Metaphors we live. Chicago: University Press.

LASI, H., FETTKE, P., KEMPER, H.G., FELD, T., \& HOFFMANN, M. (2014). Industry 4.0. Business \& Information Systems Engineering, 6, 239-242.

MANYIKA, J., CHUI M., BUGHIN, J., DOBBS, R., BISSON, P., \& MARRS, A. (2013). Disruptive technologies: advances that will transform life, business, and the global economy. San Francisco: McKinsey Global Institute.

MOKYR, J., VICKERS, C. \& ZIEBARTH, N. (2015). The History of Technological Anxiety and the Future of Economic Growth: Is this Time Different?. Journal of Economic Perspectives, 29(3), 31-50.

PATTON, M. Q. (2001). Qualitative research and evaluation and methods (3rd ed.). Beverly Hills, CA: Sage.

PEETZ, D., \& MURRAY, G. (2017). Women, Labor Segmentation and Regulation: Varieties of Gender Gaps. New York: Palgrave Macmillan.

PIANTA, M. (2018). Technology and employment: Twelve stylized facts for the digital age. The Indian Journal of Labour Economics, 61(2), 189-225.

RICHERT, A., SHEHADEH, M., PLUMANNS, L., GROß, K., SCHUSTER, K., \& JESCHKE, S. (2016, April). Educating Engineers for Industry 4.0: Virtual Worlds and Human-Robot-Teams: Empirical studies towards a new educational age. 2016 IEEE Global Engineering Education Conference (EDUCON), 142- 149, Abu Dhabi, United Arab Emirates.

SCHWAB, K. (2016). "The Fourth Industrial Revolution: what it means, how to respond", World Economic Forum, [Weblog post]. Retrieved from: https://www.weforum.org/agenda/2016/01/the-fourth-industrial-revolution-what-itmeans-and-how-to-respond/, 10.01.2021.

SCHMITT, R. (2000). Notes Towards the Analysis of Metaphor. Qualitative Research: National, Disciplinary, Methodical and Empirical Examples, 1(1).

SCHUMACHER, A., EROL, S., \& SIHN, W. (2016). A maturity model for assessing industry 4.0 readiness and maturity of manufacturing enterprises. Procedia CIRP, 52, 161-166.

OESTERREICH, T. \& TEUTEBERG, F. (2016). Understanding the implications of digitisation and automation in the context of Industry 4.0: A triangulation approach and elements of a research agenda for the construction industry. Computers in Industry, 83, 121-139.

TEHERANI, A., MARTIMIANAKIS, T., STENFORS-HAYES, T., WADHWA, A., \& VARPIO, L. (2015). Choosing a qualitative research approach. Journal of Graduate Medical Education, 7, 669-70.

THOBEN, S., WIESNER, A., \& WUEST, T. (2017). Industrie 4.0 and smart manufacturing - a review of research issues and application examples. International Journal of Automation Technology, 11(1), 1-12.

VIEIRA ALVES, A. P. S. (2020). Achieving the right to work in the face of technological advances: Reflections on the occasion of the ilo's centenary, Bologna Law Review, 5(1), 226-233. 
WEF (World Economic Forum). (2016). The future of jobs: Employment, skills and workforce strategy for the fourth industrial revolution. Geneva: World Economic Forum. 